\title{
Successful recovery of recurrence of positive SARS-CoV-2 RNA in COVID-19 patient with systemic lupus erythematosus: a case report and review
}

\author{
Feng $\mathrm{He}^{1}$ (D) Q Qingqing Luo ${ }^{1} \cdot$ Ming Lei $^{2} \cdot$ Lixin $\mathrm{Fan}^{2} \cdot$ Xinning Shao ${ }^{2} \cdot$ Kaiyuan $\mathrm{Hu}^{2}$. Shuguang Qin ${ }^{1} \cdot \mathrm{Na} \mathrm{Yu}^{1}$. \\ Jie Cao ${ }^{1} \cdot$ Liuping Yang ${ }^{2}$
}

Received: 16 May 2020 / Revised: 30 May 2020 / Accepted: 9 June 2020 / Published online: 28 July 2020

(C) International League of Associations for Rheumatology (ILAR) 2020

\begin{abstract}
COVID-19 has become a global concern. A large number of reports have explained the clinical characteristics and treatment strategies of COVID-19, but the characteristics and treatment of COVID-19 patient with systemic lupus erythematosus (SLE) are still unclear. Here, we report the clinical features and treatment of the first SLE patient with confirmed COVID-19 pneumonia. This was a 39-year-old woman, diagnosed with SLE 15 years ago, whose overall clinical characteristics (symptoms, laboratory tests, and chest CTs) were similar to those of the general COVID-19 patients. She continued to take the previous SLE drugs (doses of glucocorticoids, hydroxychloroquine, and immunosuppressive agents were not reduced) and was treated with strict antiviral and infection prevention treatment. After the first discharge, she got a recurrence of COVID-19 during her home isolation, and then returned to hospital and continued the previous therapy. Finally, this long-term immune suppressive patient's COVID-19 was successfully cured. The successful recovery of this case has significant reference value for the future treatment of COVID-19 patients with SLE.
\end{abstract}

Key Points

- COVID-19 patients with SLE is advocated to continue the medical treatment for SLE.

- Hydroxychloroquine may have potential benefits for COVID-19 patients with SLE.

- COVID-19 patients with SLE is prone to relapse, and multiple follow-ups are necessary.

Keywords COVID-19 $\cdot$ Recurrence $\cdot$ SARS-CoV-2 $\cdot$ Systemic lupus erythematosus

\section{Introduction}

Coronavirus disease 2019 (COVID-19), a newly emerged respiratory disease caused by severe acute respiratory syndrome coronavirus 2 (SARS-CoV-2), has recently become pandemic. Up to May 5, 2020, more than 3.6 million cases have been diagnosed in more than 200 countries, with a mortality rate of

$\overline{\text { Feng He, Qingqing Luo and Ming Lei contributed equally to this work. }}$

\section{Liuping Yang}

gz8hylp@126.com

1 Guangzhou First People's Hospital, The Second Affiliated Hospital of South China University of Technology, Guangzhou, China

2 Guangzhou Eighth people's hospital, Guangzhou Medical University, Guangzhou 510060, China about $7 \%$ [1]. Unfortunately, these numbers continue to increase.

Systemic lupus erythematosus (SLE) is a common autoimmune disease [2]. SLE patients have a reduced $\mathrm{CD}^{+} \mathrm{T}$ lymphocytes count $[3,4]$, a decreased $C D 8^{+} \mathrm{T}$ cell-mediated cytotoxicity, and an increased infection tendency [5]. Immunosuppressive agents and glucocorticoids are commonly used for SLE treatment $[2,6]$. Therefore, the immune response of SLE patients, especially T cell immune response, was significantly suppressed. In addition, ACE2 is known to be the main pathogenic receptor of SARS-CoV-2 virus, which is sensitive to methylation, and ACE2 is undermethylated and overexpressed on $\mathrm{CD} 4^{+} \mathrm{T}$ cells of lupus patients [7]. Thus, COVID-19 patients with SLE may be more susceptible to SARS-CoV-2, and the severity of COVID-19 disease may increase. The clinical manifestations, treatment, and prognosis of these patients may be different from those of general 
COVID-19 patients. Therefore, COVID-19 patients with SLE are very worth paying attention to and researching. However, none relevant reports have been found so far.

Here, we are the first to report the clinical manifestations, treatment, and prognosis of one COVID-19 patient with SLE. Our case report and intervention programs can provide references and warnings for the treatment of other similar patients.

\section{Case description}

This patient was a 39-year-old woman who was diagnosed with SLE in 2005. She received standard treatment with prednisone and hydroxychloroquine, and her lupus condition was relieved. In May 2018, due to lupus activity (showing as fever, arthralgia, hematuria, decreased hemoglobin, and so on), treatment with mycophenolate mofetil (MMF) (1.0 g, BID) started to be added. From November 2018 up to now, the drugs for her SLE were MMF (0.5 g, BID), prednisone (10 mg, QD), and hydroxychloroquine $(0.2 \mathrm{~g}, \mathrm{BID})$.

From Jan 21 to 25, 2020, the patient returned to Wuhan to visit her relatives. After this visit, she developed dry cough and fatigue on Feb 5 (the first day of illness). She did not pay attention and did not seek for medical treatment. She developed fever on February 11 and her highest body temperature was $37.6{ }^{\circ} \mathrm{C}$. She rested at home without medical treatment until she had difficulty breathing and sputum, with the maximum body temperature reaching $37.9^{\circ} \mathrm{C}$ on Feb 14. As the symptoms worsened, she went to the fever clinic of Guangzhou Eighth People's Hospital. These abnormalities suggested that she may have COVID-19 pneumonia. We performed reverse real-time polymerase chain reaction (PCR) analysis on throat swab samples and the result of SARSCoV-2 RNA test was positive. Then, the patient was admitted to the isolation ward on the same day.

The physical examination entering the isolation ward revealed a body temperature of $37.9^{\circ} \mathrm{C}$, a blood pressure of 126/80 mmHg, a pulse of 118 breaths per minute, and a respiratory rate of 26 breaths per minute. Finger oxygen monitoring showed that the oxygen saturation was $54 \%$. Oxygen was administered through a nasal catheter at the rate of $2 \mathrm{~L} / \mathrm{min}$.

On the second morning of admission, the patient had a body temperature of $37.3{ }^{\circ} \mathrm{C}$, a pulse rate of 91 beats per minute, and her blood gas analysis showed an oxygen saturation of $59 \%$, an oxygen partial pressure of $34 \mathrm{mmHg}$, a carbon dioxide partial pressure of $36.4 \mathrm{mmHg}$, and a $\mathrm{pH}$ value of 7.348. Oxygen was administered at the rate of $3 \mathrm{~L} / \mathrm{min}$. The laboratory test results were as follows (Table 1). Blood routine showed a decrease in white blood cells $\left(3.11 \times 10^{9} / \mathrm{L}\right)$ and lymphocyte $\left(0.73 \times 10^{9} / \mathrm{L}\right)$. Flow cytometry showed that the absolute counts of $\mathrm{CD} 45^{+}$lymphocytes $(1144$ cells $/ \mu \mathrm{L})$ and
T helper lymphocytes $\left(\mathrm{CD}^{+} \mathrm{CD}^{+}\right)(387$ cells $/ \mu \mathrm{L})$ both decreased significantly. The patient's symptoms and medication information are shown in Fig. 1. The chest CTs on February 15th showed multiple ground glass shadows and stripe shadows in the lower lobe of both lungs, which was consistent with viral pneumonia (Fig. 2a). The medications given to the patient included (i) therapeutic drugs for SLE, maintaining previous drugs and dosage. (ii) Antiviral treatment drug, lopinavir plus ritonavir tablets (250 mg, BID). (iii) Drug for preventing secondary infections, moxifloxacin (0.4 g, QD, intravenous drip) (Fig. 1).

On Feb 16, the patient's body temperature returned to normal, and shortness of breath and chest tightness were alleviated than before. On Feb 20, the patient's respiratory and digestive symptoms resolved. Further, the three retests of SARS-CoV-2 RNA by throat swabs were all negative on Feb 20, Feb 22, and Feb 24 (Fig. 1), so the antiviral drugs were stopped on Feb 25. The patient's second chest CTs on Feb 18 showed a larger range of ground glass shadows and stripe shadows in both lungs (Fig. 2a). However, the two retests of chest CTs on Feb 22 and Feb 25 showed that the lesions of both lungs gradually reduced (Fig. 2a). In addition, on Feb 25 , the counts of white blood cells $\left(4.81 \times 10^{9} / \mathrm{L}\right)$ and lymphocyte $\left(1.29 \times 10^{9} / \mathrm{L}\right)$ returned to normal level (Table 1$)$; flow cytometry analysis showed that the absolute counts of $\mathrm{CD} 45^{+}$lymphocytes $(1250 \mathrm{cells} / \mu \mathrm{L})$ and $\mathrm{T}$ helper lymphocytes $\left(\mathrm{CD}^{+}{ }^{+} \mathrm{CD}^{+}\right)(424$ cells $/ \mu \mathrm{L})$ both increased compared with before (Table 1); the serum levels of inflammatory factors were normal (Table 1). The patient felt good, and after stopping oxygen supplementation, her oxygen saturation value remains above $98 \%$. Therefore, 1 day later (Feb 26), she was discharged and was encouraged to maintain family isolation for at least 14 days.

Unexpectedly, on the 8th day of her home isolation (Mar 5), she reappeared symptoms of dry cough, arthralgia, and headache without fever. The reverse real-time PCR analysis showed that her SARS-CoV-2 RNA was positive again, with her chest CTs showing a small ground glass shadow in the lower lobe of the right lung, but the lesion in the left lung almost completely resolved (Fig. 2b). Obviously, the patient had a recurrence of COVID-19. Then, she was admitted to the isolation ward again on the same day.

On the morning of Mar 6, the patient's body temperature was $36.6{ }^{\circ} \mathrm{C}$ and the pulse rate was 87 beats per minute. The results of laboratory tests are shown in Table 1. The counts of blood leukocytes $\left(4.99 \times 10^{9} / \mathrm{L}\right)$ and lymphocyte $\left(1.16 \times 10^{9} / \mathrm{L}\right)$ were normal. She was given the same SLE treatment and antiviral treatment as the last admission (Fig. 1).

On Mar 7, her symptoms of dry cough, arthralgia, and headache were relieved. And the retests of SARS-CoV-2 RNA for 3 consecutive days were all negative from Mar 7 to Mar 9 (Fig. 1). Antiviral drug was stopped at Mar 9, and the 
Table 1 Clinical laboratory data

\begin{tabular}{|c|c|c|c|c|c|c|}
\hline Laboratory data & Reference range & Baseline Feb 15 & Re-examination Feb 25 & Recurrence Mar 5 & Follow-up Mar 23 & Follow-up Apr 11 \\
\hline $\mathrm{WBC}\left(\times 10^{9} / \mathrm{L}\right)$ & $3.5-9.5$ & 3.11 & 4.81 & 4.99 & 4.76 & 4.57 \\
\hline NEUT $\left(\times 10^{9} / \mathrm{L}\right)$ & $1.8-6.3$ & 2.08 & 3.01 & 3.26 & 3.01 & 2.72 \\
\hline NEUT (\%) & $40-75$ & 66.90 & 62.6 & 65.4 & 63.2 & 59.4 \\
\hline $\operatorname{LYM}\left(\times 10^{9} / \mathrm{L}\right)$ & $1.1-3.2$ & 0.73 & 1.29 & 1.16 & 1.18 & 1.36 \\
\hline LYM (\%) & $20-50$ & 23.5 & 26.8 & 23.2 & 24.8 & 29.8 \\
\hline $\operatorname{MONO}\left(\times 10^{9} / \mathrm{L}\right)$ & $0.1-0.6$ & 0.29 & 0.47 & 0.51 & 0.5 & 0.42 \\
\hline MONO (\%) & $3-10$ & 9.3 & 9.8 & 10.2 & 10.5 & 9.2 \\
\hline $\operatorname{PLT}\left(\times 10^{9} / \mathrm{L}\right)$ & $125-350$ & 156 & 335 & 127 & 134 & 308 \\
\hline Hemoglobin $(\mathrm{g} / \mathrm{L})$ & $115-150$ & 96 & 81 & 83 & 84 & 99 \\
\hline Urine protein & negative & negative & negative & negative & negative & negative \\
\hline Urine gravity & $1.003-1.030$ & 1.013 & 1.016 & 1.015 & 1.020 & 1.017 \\
\hline pO2 (mmHg) & $83-108$ & 34.0 & 101 & - & - & - \\
\hline $\mathrm{sO} 2(\%)$ & $92-98$ & 58.9 & 98 & - & - & - \\
\hline $\mathrm{pCO} 2(\mathrm{mmHg})$ & $35-45$ & 36.4 & 34.2 & - & - & - \\
\hline $\mathrm{K}^{+}(\mathrm{mmol} / \mathrm{L})$ & $3.4-4.5$ & 3.4 & 3.5 & 3.7 & 4.09 & 3.39 \\
\hline $\mathrm{Na}^{+}(\mathrm{mmol} / \mathrm{L})$ & $136-146$ & 143 & 144 & 145 & 142 & 140 \\
\hline $\mathrm{Cl}(\mathrm{mmol} / \mathrm{L})$ & $98-106$ & 111 & 111 & 109 & 108 & 108 \\
\hline $\mathrm{Ca}(\mathrm{mmol} / \mathrm{L})$ & $2.11-2.52$ & 2.09 & 2.02 & 2.11 & 2.15 & 2.12 \\
\hline $\mathrm{D}$-dimer (mg/L) & $<1000$ & 910 & & & & \\
\hline $\operatorname{ALT}(\mathrm{U} / \mathrm{L})$ & $7-40$ & 9.1 & 13.5 & 12.1 & 11 & 11.1 \\
\hline $\mathrm{AST}(\mathrm{U} / \mathrm{L})$ & $13-35$ & 12.5 & 12 & 11.8 & 12.2 & 13.6 \\
\hline Albumin $(\mathrm{g} / \mathrm{L})$ & $40-55$ & 38.3 & 33.7 & 36.7 & 40.5 & 45.8 \\
\hline Creatinine $(\mu \mathrm{mol} / \mathrm{L})$ & $41-81$ & 47.7 & 42.6 & 48.8 & 51.1 & 50.0 \\
\hline Urea nitrogen $(\mathrm{mmol} / \mathrm{L})$ & $2.6-8.8$ & 2.5 & 2.17 & 3.04 & 2.96 & 3.03 \\
\hline eGFR $\left(\mathrm{mL} / \mathrm{min} / 1.73 \mathrm{~m}^{2}\right)$ & $>90$ & 164.7 & 188.7 & 161.3 & 151.7 & 154 \\
\hline $\mathrm{TNI}(\mu \mathrm{g} / \mathrm{L})$ & $<0.03$ & 0.001 & 0.007 & - & - & - \\
\hline Myoglobin $(\mu \mathrm{g} / \mathrm{L})$ & $14.3-65.8$ & 13.9 & 11 & - & - & - \\
\hline CK-MB (U/L) & $0.6-6.3$ & 0.5 & 0.8 & - & - & 5.0 \\
\hline hs-CRP (mg/L) & & 7.36 & $<0.5$ & $<0.5$ & $<0.5$ & 0.0 \\
\hline $\mathrm{CRP}(\mathrm{mg} / \mathrm{L})$ & $<10$ & $<10$ & $<10$ & $<10$ & $<10$ & $<10$ \\
\hline PCT (ng/mL) & $<0.05$ & $>0.05$ & & $>0.05$ & & \\
\hline $\mathrm{CD} 45^{+}($cells $/ \mu \mathrm{L})$ & $1488-4483$ & 1144 & 1250 & - & - & 1329 \\
\hline $\mathrm{CD}^{+} \mathrm{CD}^{2} 5^{+}($cells $/ \mu \mathrm{L})$ & $955-2860$ & 999 & 1129 & - & - & 1218 \\
\hline $\mathrm{CD} 3^{+} \mathrm{CD} 45^{+}(\%)$ & $50-84$ & 87 & 90 & - & - & 92 \\
\hline $\mathrm{CD}^{+} \mathrm{CD}^{+}($cells $/ \mu \mathrm{L})$ & $550-1440$ & 385 & 424 & - & - & 425 \\
\hline $\mathrm{CD}^{+} \mathrm{CD}^{+}(\%)$ & $26-61$ & 34 & 34 & - & - & 32 \\
\hline $\mathrm{CD}^{+} \mathrm{CD}^{+}($cells $/ \mu \mathrm{L})$ & $320-1250$ & 592 & 680 & - & - & 774 \\
\hline $\mathrm{CD}^{+} \mathrm{CD}^{+}(\%)$ & $15-44$ & 52 & 54 & - & - & 58 \\
\hline $\mathrm{CD} 3^{+} \mathrm{CD} 4^{+} \mathrm{CD} 8^{+}($cells $/ \mu \mathrm{L})$ & & 7 & 8 & - & - & 14 \\
\hline $\mathrm{CD}^{+} \mathrm{CD}^{+} \mathrm{CD} 8^{+} / \mathrm{CD} 45^{+}(\%)$ & & 1 & 1 & - & - & 1 \\
\hline $\mathrm{CD}^{+} / \mathrm{CD}^{+}(\%)$ & $1.2-2.0$ & 0.65 & 0.62 & - & - & 0.55 \\
\hline IL-2 & $0-5.71$ & - & 2.17 & - & - & - \\
\hline IL-4 & $0-2.80$ & - & 1.61 & - & - & - \\
\hline IL-6 & $0-5.30$ & - & 2.48 & - & - & 2.49 \\
\hline IL-10 & $0-4.91$ & - & 1.76 & - & - & - \\
\hline TNF- $\alpha$ & $0-2.31$ & - & 1.24 & - & - & - \\
\hline IFN- $\gamma$ & $0-7.42$ & - & 0.27 & - & - & - \\
\hline
\end{tabular}

Note: Values in italics were either above normal or below normal

WBC white blood cell, NEUT neutrophil, LYM lymphocyte, MONO monocyte, PLT platelet, ALT alanine aminotransferase, AST aspartate aminotransferase, $e G F R$ estimated glomerular filtration rate, $T N I$ troponin I, $C K-M B$ creatine kinase-MB, $C R P$ C-reactive protein, $P C T$ procalcitonin, $I L$ interleukin, $T N F$ tumor necrosis factor, $I F N-\gamma$ interferon- $\gamma$

patient felt good and was discharged. The doctor encouraged her to maintain home isolation for at least 14 days and recommended her to follow-up. After 2 weeks of isolation, the patient returned to hospital twice for follow-up on Mar 23 and Apr 11 (Fig. 1). Both re-examinations of SARS-CoV-2 RNA were negative, and the latest chest $\mathrm{CTs}$ showed that the lesions of both lungs almost completely resolved (Fig. 2c). Now, she is in good condition and has returned to work.

\section{Discussion}

Since SLE patients are more sensitive to SARS-CoV-2 virus than general population [5,7], it is essential to maintain the established treatment of lupus patients during the COVID-19 pandemic to ensure the stable lupus condition [8]. For such special patients, we need to carefully weigh the relationship between SLE and COVID-19 
pneumonia and consider a two-pronged treatment plan. For SLE, in order to reduce the susceptibility to SARS$\mathrm{CoV}-2$ virus as well as to prevent the recurrence or activity of SLE, we continued to use anti-rheumatic drugs and did not stop immunosuppressive agents and glucocorticoids. For COVID-19, due to the lack of specific drugs [9], we use antiviral drugs, infection prevention, oxygen therapy, and other symptomatic supportive treatment to relieve symptoms.

During the patient's twice admissions for COVID-19 pneumonia, we continued her previous SLE treatment regimen and did not reduce the dosage, which bring the following benefits: (i) this drug formulation can control the condition of SLE and prevent its recurrence or activity [6]; (ii) the anti-inflammatory effect of glucocorticoids can reduce alveolar exudation [10], and glucocorticoids is also the first-line drug to prevent and alleviate cytokine storms [11], which may be the reason for the patient's inflammatory factors (IL-2, TNF- $\alpha$, etc.) being at normal levels (Table 1); (iii) in addition to being a traditional drug for SLE [12], hydroxychloroquine has been reported to be effective in inhibiting SARS-CoV-2 virus [13, 14], so hydroxychloroquine may have a multiplier effect on COVID-19 patients with SLE, which deserves high attention and in-depth discussion.

Reports about the treatment of COVID-19 with hydroxychloroquine were inconsistent. Previous studies have shown that chloroquine phosphate had a wide range of antiviral effects, including anti-coronavirus [14]. Chloroquine exerts its ability to inhibit viral replication by reducing the terminal glycosylation of the ACE2 receptor and interfering with the combination of coronavirus and ACE2 receptor [15-17]. A report found that COVID-19 patients have the characteristics of rheumatic diseases [18], such as arthralgia, acute interstitial pneumonia, myocarditis, leukopenia, lymphopenia, thrombocytopenia, and cytokine storms, etc. Thus, anti-rheumatic drugs (such as hydroxychloroquine) may be effective for COVID-19. Recently, the Emergency Use Authorization (EUA) has allowed the use of hydroxychloroquine to treat COVID-19 hospitalized adults and adolescents when the potential benefit outweighs the potential risk, but FDA has not yet approved the use of hydroxychloroquine in COVID-19 patients [19]. There were also reports that thought there was no absolute data to support the effect of hydroxychloroquine on COVID-19, instead, patients may have to suffer from the side effects caused by it [20]. More clinical studies are still needed to confirm the effect of hydroxychloroquine in the future. According to the recommendations of international rheumatologists, the use of anti-rheumatic drugs should not be stopped or reduced during the COVID-19 epidemic [21-24], and hydroxychloroquine is the optimal choice [22]. For the case we reported, she has taken hydroxychloroquine for 15 years without interruption since she diagnosed with SLE in 2005, with no noticeable side effects occurring. Therefore, it was necessary and safe for her to continue to use hydroxychloroquine. In addition, the potential benefits of hydroxychloroquine on COVID-19 gave us more confidence and encouragement to use hydroxychloroquine on this patient.

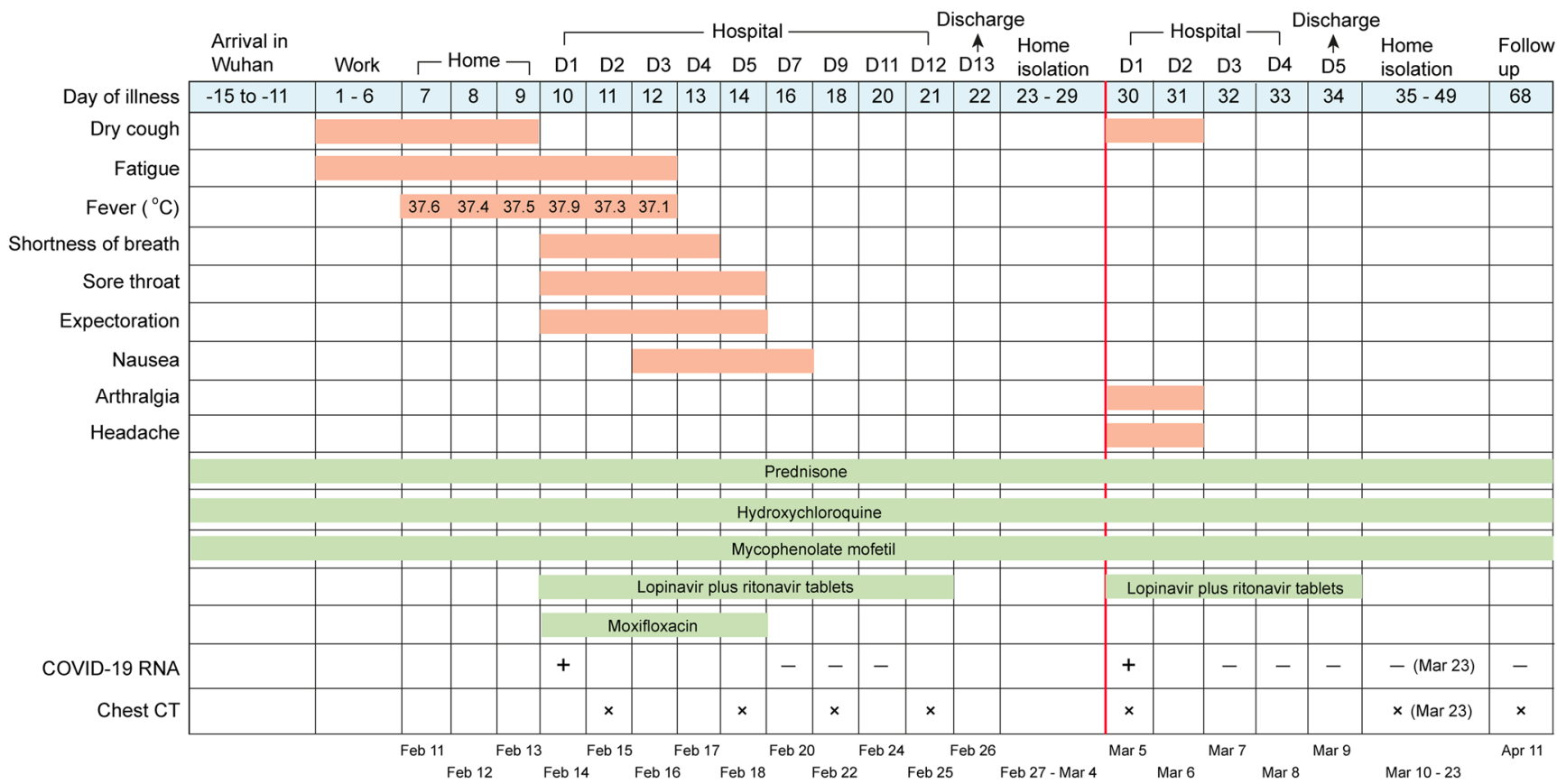

Fig. 1 Timeline of disease course according to days from initial presentation of illness and days from hospital admission. + means SARS-CoV-2 RNA is positive. - means SARS-CoV-2 RNA is negative. $\mathrm{x}$ means chest $\mathrm{CT}$ is done on that day 
Fig. 2 High-resolution computed

tomography images of twice

hospital admission and twice follow-ups. a CTs after the first hospital admission, multiple ground glass density lesions were observed in the lower lobe of the bilateral lung. b CTs after the recurrence of positive SARSCoV-2 RNA. c CTs during follow-up. The red arrows indicate the lesions
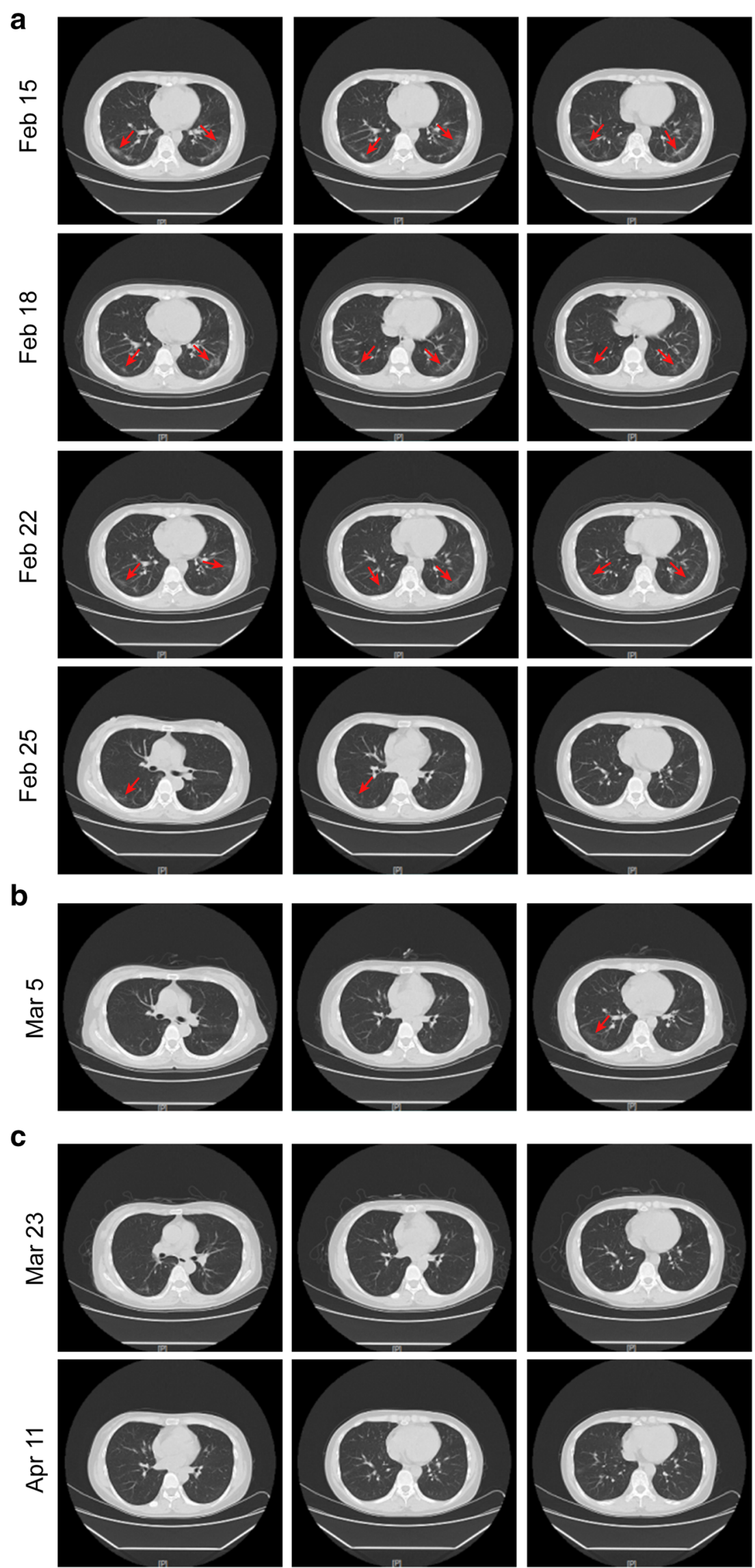

黑 Springer 
This patient had an interesting manifestation. We took her peripheral blood for flow cytometry testing and found that the results were slightly different from those of general COVID19 patients. Qin et al. found that $\mathrm{CD} 4^{+} \mathrm{T}$ cells and $\mathrm{CD} 8^{+} \mathrm{T}$ cells in COVID-19 patients were lower than normal levels, while the levels of $\mathrm{CD} 4^{+} \mathrm{T}$ cells in critically ill patients were lower [25]. Xu's research showed that the counts of $\mathrm{CD}^{+} \mathrm{T}$ cells and $\mathrm{CD} 8^{+} \mathrm{T}$ cells in the peripheral blood of COVID-19 patients were greatly reduced, but $\mathrm{CD} 8^{+} \mathrm{T}$ cells had excessive activation showing high cytotoxicity, which led to severe immune injury [26]. In the multivariate analysis of Wang et al., the count of $\mathrm{CD}^{+} \mathrm{T}$ cells and the ratio of $\mathrm{CD} 4^{+} / \mathrm{CD} 8^{+}$were independent predictors of COVID-19's disease severity and treatment effect [27]. Our patient's peripheral blood flow cytometry at the time of the first admission showed that the $\mathrm{CD}^{+} \mathrm{T}$ cells were also significantly reduced, but unlike general COVID-19 patients, her $\mathrm{CD}^{+} \mathrm{T}$ cells were not lower than the normal value, while its proportion somewhat rose (Table 1). This phenomenon may be related to the fact that SLE disease made the patient's $\mathrm{CD}^{+} \mathrm{T}$ cells significantly reduced, which indirectly leads to an increase in the proportion of $\mathrm{CD} 8^{+} \mathrm{T}$ cells $[3,4]$. After treatment, the count and ratio of $\mathrm{CD}^{+} \mathrm{T}$ cells were continuously increasing, and the ratio of $\mathrm{CD}^{+} / \mathrm{CD}^{+}$was decreasing (Table 1 ), which suggested that her treatment effect and prognosis were good.

The main feature of this case was the recurrence of COVID-19 during the home isolation after the first discharge, with the pharyngeal swab detection of SARS-CoV-2 RNA being positive again. We proposed several possible reasons for her recurrence as follows: (i) long-term use of the glucocorticoid. Prednisone and the immunosuppressive agent MMF weakened the patient's immune system, which was not conducive to the removal of the virus; (ii) depending on the sample collection site, the operator's experience, and actual viral load, false negative results may sometimes occur in oropharyngeal or nasopharyngeal swab tests [28]; (iii) SARSCoV-2 RNA in respiratory specimens may be persistent or recurrently positive during the disease process; (iv) because the viral receptor ACE2 is highly expressed in the lungs rather than in the upper respiratory tract $[29,30]$, specimen test of the bronchoalveolar lavage fluid (BALF) is considered more accurate than oropharyngeal or nasopharyngeal swabs, but the risk of exposure is higher; (v) this patient may accidentally infect SARS-CoV-2 again after her first discharge.

After analysis, we thought this patient may have two conditions when she discharged for the first time. One is the patient reached the discharge standard, but the virus was temporarily suppressed at a very low concentration, which was difficult to be detected. During the home isolation, the virus gradually replicated and was detected positive. The other is the patient's condition improved indeed at that time, but the result of the virus RNA test was false negative, and the test result during isolation was true. In either condition, we have reason to believe that SARS-CoV-2 virus in SLE patients is difficult to be completely removed and prone to relapse. In addition to COVID-19 patients, asymptomatic carriers and patients in recovery may also be contagious. So, COVID-19 patients with SLE require more observation and testing than general COVID-19 patients.

In conclusion, we are the first to report the clinical features, treatment, and prognosis of one COVID-19 case with SLE. This patient had comprehensive clinical manifestations of SLE and COVID-19 [2, 31], but no other special symptoms or abnormalities have been found. We continued her previous SLE treatment strategy, combined with antiviral, anti-infective, and oxygen therapy to treat COVID-19 pneumonia, and her disease quickly resolved. Notably, the patient had a recurrence after her first discharge from hospital and the viral RNA detection became positive again. This suggests that there may exist a window period of asymptomatic infection after the discharge of COVID-19 patients with SLE, in which such patients may spread the virus outward. Therefore, we strongly recommend COVID-19 patients with SLE to be strictly quarantined at home for more than 14 days after discharge and then returned to hospital for follow-up and review at least twice. Only multiple virus RNA tests are all negative and chest $\mathrm{CTs}$ show a marked improvement in lung lesions, can the patients be declared cured [32].

However, we also realized that only one successfully cured case cannot define an effective treatment guideline for this type of patients. The patient in our report recovered well, which may also be related to her young age [33] and her fair basic condition, with no other risk factors leading to severe COVID-19 [34, 35], such as comorbidities (hypertension, diabetes, etc.) and ARDS. The treatments she received in hospital helped the recovery of her disease, but it was difficult to deduce treatment guidelines for other similar patients. In the future, we need to collect a large number of COVID-19 cases with SLE and accumulate more experience and data to optimize the treatment strategy for such patients. At present, our case report and treatments have at least played a role of reference and warning for other COVID-19 patients with SLE.

\section{Code availability Not applicable.}

Authors' contributions LY conceived the study. FH, QL, and ML designed the study. LY supervised the overall study. LF, XS, and $\mathrm{KH}$ collected clinical data, laboratory data, chest CT images, and did the flow cytometry test. FH, QL, and ML analyzed and interpreted the data above. SQ, NY, and JC made the tables and figures. ML searched the literature. FH and QL wrote the manuscript. LY critically revised the manuscript. All authors have reviewed the final version of the manuscript and have approved it for publication.

Funding information We declare no funds.

Data availability Not applicable. 


\section{Compliance with ethical standards}

Disclosures None.

Ethics approval This study was approved by the ethics committees of Guangzhou First People's Hospital and Guangzhou Eighth People's Hospital.

Consent to participate Written informed consent was obtained from patients.

Consent for publication Written informed consent was obtained from patients for publication.

\section{References}

1. COVID-19 cases worldwide. Available from: https://www. worldometers.info/coronavirus/. Accessed 30 Apr 2020

2. Rahman A, Isenberg DA (2008) Systemic lupus erythematosus. N Engl J Med 358(9):929-939

3. Miyara M, Amoura Z, Parizot C, Badoual C, Dorgham K, Trad S, Nochy D, Debré P, Piette JC, Gorochov G (2005) Global natural regulatory $\mathrm{T}$ cell depletion in active systemic lupus erythematosus. J Immunol 175(12):8392-8400

4. Yang J, Yang X, Zou H, Chu Y, Li M (2011) Recovery of the immune balance between Th17 and regulatory T cells as a treatment for systemic lupus erythematosus. Rheumatology (Oxford) 50(8): 1366-1372

5. Katsuyama E, Suarez-Fueyo A, Bradley SJ, Mizui M, Marin AV, Mulki L et al (2020) The CD38/NAD/SIRTUIN1/EZH2 axis mitigates cytotoxic $\mathrm{CD} 8 \mathrm{~T}$ cell function and identifies patients with SLE prone to infections. Cell Rep 30(1)

6. Gordon C, Amissah-Arthur M-B, Gayed M, Brown S, Bruce IN, D'Cruz D et al (2018) The British Society for Rheumatology guideline for the management of systemic lupus erythematosus in adults. Rheumatology (Oxford) 57(1)

7. Sawalha AH, Zhao M, Coit P, Lu Q (2020) Epigenetic dysregulation of ACE2 and interferon-regulated genes might suggest increased COVID-19 susceptibility and severity in lupus patients. Clin Immunol 215:108410

8. Michaud K, Wipfler K, Shaw Y, Simon TA, Cornish A, England BR, Ogdie A, Katz P (2020) Experiences of patients with rheumatic diseases in the US during early days of the COVID-19 pandemic. ACR Open Rheumatol

9. Pang J, Wang MX, Ang IYH, Tan SHX, Lewis RF, Chen JIP, Potential Rapid Diagnostics et al Vaccine and Therapeutics for 2019 Novel coronavirus (2019-nCoV): a systematic review. J Clin Med 2020, 9(3)

10. Zhu L, Xu X, Ma K, Yang J, Guan H, Chen S, Chen Z, Chen G (2020) Successful recovery of COVID-19 pneumonia in a renal transplant recipient with long-term immunosuppression. Am J Transplant

11. Henderson LA, Canna SW, Schulert GS, Volpi S, Lee PY, Kernan $\mathrm{KF}$ et al (2020) On the alert for cytokine storm: Immunopathology in COVID-19. Arthritis \& rheumatology (Hoboken, NJ)

12. Savarino A, Boelaert JR, Cassone A, Majori G, Cauda R (2003) Effects of chloroquine on viral infections: an old drug against today's diseases? Lancet Infect Dis 3(11):722-727

13. Gao J, Tian Z, Yang X (2020) Breakthrough: Chloroquine phosphate has shown apparent efficacy in treatment of COVID-19 associated pneumonia in clinical studies. Biosci Trends 14(1):72-73
14. (2020) Expert consensus on chloroquine phosphate for the treatment of novel coronavirus pneumonia. Zhonghua Jie $\mathrm{He} \mathrm{He} \mathrm{Hu}$ Xi Za Zhi 43(3):185-188

15. Wang M, Cao R, Zhang L, Yang X, Liu J, Xu M, Shi Z, Hu Z, Zhong W, Xiao G (2020) Remdesivir and chloroquine effectively inhibit the recently emerged novel coronavirus (2019-nCoV) in vitro. Cell Res 30(3):269-271

16. Xu X, Chen P, Wang J, Feng J, Zhou H, Li X, Zhong W, Hao P (2020) Evolution of the novel coronavirus from the ongoing Wuhan outbreak and modeling of its spike protein for risk of human transmission. Sci China Life Sci 63(3):457-460

17. Vincent MJ, Bergeron E, Benjannet S, Erickson BR, Rollin PE, Ksiazek TG, Seidah NG, Nichol ST (2005) Chloroquine is a potent inhibitor of SARS coronavirus infection and spread. Virol J 2:69

18. Misra DP, Agarwal V, Gasparyan AY, Zimba O (2020) Rheumatologists' perspective on coronavirus disease 19 (COVID19) and potential therapeutic targets. Clin Rheumatol

19. FDA Issues FAQs on Emergency Use Authorization for Hydroxychloroquine and Chloroquine. Available from: https:// www.rheumatology.org/Portals/0/Files/FAQs-EUA-ChloroquinePhosophate-Hydroxychloroquine-Sulfate-Certain-COVID-19Patients.pdf. Accessed 27 Apr 2020

20. Yazdany J, Kim AHJ (2020) Use of hydroxychloroquine and chloroquine during the COVID-19 pandemic: what every clinician should know. Ann Intern Med 172:754-755

21. EULAR guidance for patients during Covid-19 outbreak. Mar 17, 2020. Available from: https://www.eular.org/eular_guidance_for_ patients_covid19_outbreak.cfm. Accessed 27 Apr 2020

22. BSR guidance for patients during Covid-19 outbreak. Apr 23, 2020. Available from: https://www.rheumatology.org.uk/NewsPolicy/Details/Covid19-Coronavirus-update-members. Accessed 27 Apr 2020

23. Australian Rheumatology Association guidance for patients during Covid-19 outbreak. Mar 17, 2020. Available from: https:// arthritisaustralia.com.au/advice-regarding-coronavirus-covid-19from-the-australian-rheumatology-association/. Accessed $27 \mathrm{Apr}$ 2020

24. ACR guidance for patients during Covid-19 outbreak. Apr 14, 2020. Available from: https://www.rheumatology.org/ announcements. Accessed 27 Apr 2020

25. Qin C, Zhou L, Hu Z, Zhang S, Yang S, Tao Y et al (2020) Dysregulation of immune response in patients with COVID-19 in Wuhan, China. Clin Infect Dis

26. Xu Z, Shi L, Wang Y, Zhang J, Huang L, Zhang C, Liu S, Zhao P, Liu H, Zhu L, Tai Y, Bai C, Gao T, Song J, Xia P, Dong J, Zhao J, Wang FS (2020) Pathological findings of COVID-19 associated with acute respiratory distress syndrome. Lancet Respir Med 8(4): $420-422$

27. Wang F, Nie J, Wang H, Zhao Q, Xiong Y, Deng L, Song S, Ma Z, Mo P, Zhang Y (2020) Characteristics of peripheral lymphocyte subset alteration in COVID-19 pneumonia. J Infect Dis 221: $1762-1769$

28. Chen D, Xu W, Lei Z, Huang Z, Liu J, Gao Z, Peng L (2020) Recurrence of positive SARS-CoV-2 RNA in COVID-19: a case report. Int J Infect Dis 93:297-299

29. Zhou P, Yang X-L, Wang X-G, Hu B, Zhang L, Zhang W, Si HR, Zhu Y, Li B, Huang CL, Chen HD, Chen J, Luo Y, Guo H, Jiang RD, Liu MQ, Chen Y, Shen XR, Wang X, Zheng XS, Zhao K, Chen QJ, Deng F, Liu LL, Yan B, Zhan FX, Wang YY, Xiao GF, Shi ZL (2020) A pneumonia outbreak associated with a new coronavirus of probable bat origin. Nature. 579(7798):270-273

30. Lu R, Zhao X, Li J, Niu P, Yang B, Wu H, Wang W, Song H, Huang B, Zhu N, Bi Y, Ma X, Zhan F, Wang L, Hu T, Zhou H, Hu Z, Zhou W, Zhao L, Chen J, Meng Y, Wang J, Lin Y, Yuan J, Xie Z, Ma J, Liu WJ, Wang D, Xu W, Holmes EC, Gao GF, Wu G, Chen W, Shi W, Tan W (2020) Genomic characterisation and 
epidemiology of 2019 novel coronavirus: implications for virus origins and receptor binding. Lancet. 395(10224):565-574

31. Guan W-J, Ni Z-Y, Hu Y, Liang W-H, Ou C-Q, He J-X, Liu L, Shan H, Lei CL, Hui DSC, du B, Li LJ, Zeng G, Yuen KY, Chen RC, Tang CL, Wang T, Chen PY, Xiang J, Li SY, Wang JL, Liang ZJ, Peng YX, Wei L, Liu Y, Hu YH, Peng P, Wang JM, Liu JY, Chen Z, Li G, Zheng ZJ, Qiu SQ, Luo J, Ye CJ, Zhu SY, Zhong NS, China Medical Treatment Expert Group for Covid-19 (2020) Clinical characteristics of coronavirus disease 2019 in China. N Engl J Med 382:1708-1720

32. National Health Commission of the People's Republic of China. Chinese diagnosis and treatment guideline for COVID-19 (version 6.0). Available from: http://www.nhc.gov.cn/yzygj/s7653p/ 202002/8334a8326dd94d329df351d7da8aefc2/files/ b218cfeb1bc54639af227f922bf6b817. Accessed 27 Apr 2020

33. Zhou F, Yu T, Du R, Fan G, Liu Y, Liu Z et al (2020) Clinical course and risk factors for mortality of adult inpatients with
COVID-19 in Wuhan, China: a retrospective cohort study. Lancet. 395(10229):1054-1062

34. Yang X, Yu Y, Xu J, Shu H, Xia J, Liu H et al (2020) Clinical course and outcomes of critically ill patients with SARS-CoV-2 pneumonia in Wuhan, China: a single-centered, retrospective, observational study. Lancet Respir Med

35. Huang C, Wang Y, Li X, Ren L, Zhao J, Hu Y, Zhang L, Fan G, Xu J, Gu X, Cheng Z, Yu T, Xia J, Wei Y, Wu W, Xie X, Yin W, Li H, Liu M, Xiao Y, Gao H, Guo L, Xie J, Wang G, Jiang R, Gao Z, Jin Q, Wang J, Cao B (2020) Clinical features of patients infected with 2019 novel coronavirus in Wuhan. China Lancet 395(10223):497506

Publisher's note Springer Nature remains neutral with regard to jurisdictional claims in published maps and institutional affiliations. 